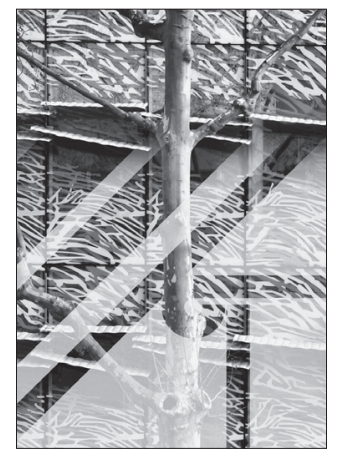

DOI: $10.37190 /$ arc210102

\title{
Ewa Netczuk-Pol*
}

\author{
The influence of the foreign invader \\ on the shape of wooden architecture \\ of the end of the $19^{\text {th }}$ and beginning of the $20^{\text {th }}$ century \\ in the Lublin region
}

\section{Introduction}

The area of the present-day Lublin region ${ }^{1}$ at the turn of the $19^{\text {th }}$ and $20^{\text {th }}$ centuries was under Russian influences. The architecture that emerged in this area was very distinct due to its unique form, which resulted from the combination of traditional Russian folk architecture with local art. Two cultures - Polish and Russian - intertwined here. This was largely due to the foreign invader government, which introduced its laws into these areas. After the fall of the January Uprising, the tsarist policy towards Poles changed. Russification intensified, along with efforts to limit the freedoms of citizens in all spheres of public life, which also affected architecture. The invader sought to close all universities in the Kingdom of Poland. In their place, new ones with Russian as the language of instruction were created. Architecture adepts could acquire knowledge only at Russian universities and at the Polytechnic Institute in Warsaw, which was greatly influenced by the invader. In this way, some new patterns were introduced into the newly emerging architecture. At that time, numerous buildings were also modernized, thus receiving features of the national Russian (pseudo-Russian) style [1].

The subject of the study is to present the influence of the invader on the appearance and architectural form of

* ORCID: 0000-0002-2514-8314. Faculty of Architecture, Wrocław University of Science and Technology, e-mail: ewa.pol@pwr.edu.pl

1 The research area was limited to the area of the present Lublin region. During the discussed period, numerous changes to the borders of the Lubelskie Voivodeship took place, hence the present area of the Lublin region was adopted for consideration. wooden residential buildings that were erected in the $\mathrm{Lu}-$ blin region during the Russian partition and in the first years after Poland regained independence, when the building regulations issued by the occupant were still in force. So far, there have been few studies containing general information on wooden buildings. Worth mentioning here are works by, e.g. Professor Wiktor Zin [2] or Jan Górak ${ }^{2}$. Both of them studied wooden architecture in this area, but without taking into account the influence of the invader on the character of the dwelling house.

\section{Historical background}

As a result of three partitions, the State of Poland disappeared from the map of Europe. Under the Treaty of Tylża (July 7, 1807), Poland received a substitute for independence in the form of the Duchy of Warsaw, which was to be ruled by Frederick Augustus, the Saxon king of the Wettin dynasty. The Lublin region was then entirely within the borders of the Duchy in 1809. After Napoleon's defeat at Moscow, which resulted in the Treaty of Vienna, in 1815 another breakthrough took place. The greater part of the Duchy of Warsaw was incorporated into the Kingdom of Poland under the reign of Tsar Alexander I and was joined by a personal union with Russia [5]. The territory of the Congress Kingdom was divided into ten governorates (Warsaw, Płock, Łomża, Suwałki, Kaliska, Piotrków, Kielce, Radom, Lublin, Chełm), which were further divided into 82 poviats (Russian: ujeździe).

\footnotetext{
2 The more important publications include: [3], [4]
} 


\section{Lublin region during the period of the Kingdom of Poland}

The area of the entire Lublin region was within the borders of the Kingdom of Poland. It was divided between two voivodships (governorates): Lubelskie and Siedlce (in the years 1837-1844 as Podlasie). The outbreak of the November Uprising in 1830 and the entry of Russian troops into the Lublin region in 1831 caused significant damage to this region. Lubartów, Kazimierz and Puławy were particularly affected. Szczebrzeszyn and Zamość also suffered significant losses [6]. Not only was the economy of the Kingdom affected, but also its autonomy. With the fall of the November Uprising, Tsar Nicholas I abolished the constitution in force from 1815 in favour of an organic statute [7]. It was aimed at even greater dependence on the Russian authorities, with little internal autonomy. It also introduced a change of the name of the voivodship to the governorate [8].

The January Uprising that broke out on January 22, 1863, after its fall, brought about even greater repressions on the part of the invader. The tsarist authorities decided to accelerate the process of Russification. As part of the reforms, a new division into governorates was made. Two poviats were separated in the Lublin region: Lublin, which included the following poviats: Lubelski, Garwolin, Janowski, Krasnystaw, Lubartowski, Łuków, Puławy, Siedlecki, Sokołowski, and Chełm with the following poviats: Chełm, Biłgoraj, Hrubieszowski, Konstantynów, Włodzimierz [9]. Not only the boundaries of voivodships have changed, but also the borders of settlement units. In 1867, a Special Committee for the Reorganization of City Council and City Economy was established. Its purpose was to verify the previously granted municipal rights to small towns.

Cities with fewer than three thousand inhabitants were to be deprived of their rights (town privileges), with at least $50 \%$ of the population living on agriculture. The activities of the Reorganization Committee brought about big changes. Over $75 \%$ of all cities in the Kingdom of Poland have been degraded to the rank of a settlement. As a result of these efforts, only 13 cities remained in the Lublin governorate, of which Kraśnik lost its municipal rights in 1878, and in 1906 they were restored to Puławy. On the other hand, there were ten towns in the Siedlce governorate. City boards were also transformed and municipalities were deprived of their autonomy. In this way, the possibilities for the development of many settlements were eliminated. Additionally, in 1912, the former Chełm governorate was created in the eastern part of the Lublin and Siedlce governorates, which after the outbreak of World War I was separated from the Kingdom of Poland and incorporated into the Russian Empire [10].

\section{Russification of society}

The suppression of the January Uprising started a period of increased repression on the part of the Russian authorities on the grounds of nationality. A special body was established in St. Petersburg to liquidate all the autonomous institutions of the Kingdom.
The tsarist repressions also spread to the socio-cultural sphere, ruining the foundations of Polish culture. The tsarist authorities banned the creation of all types of scientific, cultural and economic organizations. At the same time, total censorship was introduced [11]. Architecture became one of the elements of the Russification program, in which it was common to rebuild the forcibly taken over Roman Catholic churches, as well as former Greek Catholic churches into Orthodox churches. They were given elements characteristic of the national Russian style, developing in the $19^{\text {th }}$ century first on the basis of romanticism, and then eclecticism with numerous elements of folk tradition. At that time, over two hundred Orthodox churches were built, of which only over twenty were built from scratch [12]. In addition, military facilities were built, incl. military barracks, forts.

Professional education was abolished, which was to significantly affect the appearance of future architecture [13]. In 1832, the Institute of Civil Engineers was established at the Tsarist Academy of Fine Arts in St. Petersburg, educating young architects from the Russian partition [1]. It was not until 1898 that the Polytechnic Institute in Warsaw was established, in which, among others, engineering and construction field. The trends prevailing in Russia also significantly influenced the process and program of education there [14].

\section{Regulations}

The binding legal regulations in the field of construction had a significant impact on the shape of buildings. The oldest regulations regulating construction principles defined location privileges and their subsequent approvals granted to cities by their owners. Most of the towns were founding centres, operating mainly under the Magdeburg Law and later privileges until the beginning of the $19^{\text {th }}$ century. Numerous fires accompanying the wars of the $17^{\text {th }}$ century and natural disasters in the $18^{\text {th }}$ century destroyed the wooden buildings of the Lublin region many times. However, the reconstruction took place in a chaotic manner. For this reason, as early as the mid- $17^{\text {th }}$ century, legal regulations were introduced, modelled on regulations from other cities, aimed at limiting the spread of fires. In addition to the municipal fire and order service (the so-called $2^{\text {nd }}$ ordinance in the Magdeburg Law), laws were introduced to protect houses against fire ${ }^{3}$ [15]. Houses were ordered to be covered at least with clay-covered shingles. However, the thatch, made of straw dipped in clay, was still more common, although compliance with these provisions was not properly supervised.

The first general regulations governing the construction industry in the Polish-Lithuanian Commonwealth were passed in 1764. They mainly concerned the buildings of Warsaw, later they were extended to larger cities such as Lviv and Vilnius.

In 1784, the Boni Ordinis Commission passed a ban on building non-refractory houses within the city limits

${ }^{3}$ For example, the instruction of Jan Daniłowicz issued in 1644 after the fire of his town Międzyrzec was checked in the Landwójtowska Book. 
within their walls and ordered the relocation of, among others, workshops, bakeries and forges in the suburbs. The first regulations covering the entire territory of the country appeared in 1791 . They concerned the ban on the use of roof coverings made of flammable material, which were mainly thatch and shingles. Moreover, wooden buildings were forbidden to be built in larger cities. Municipalities of individual cities could additionally create regulations of local importance, after obtaining the consent of the Police Commission. The building law of the Duchy of Warsaw forbade construction without submitting an appropriate architectural design to the appropriate police authority [16].

In the first years of the Kingdom of Poland, the legal acts contained in Przepisy Ogólne Policji Budowlanej dla miast w Królestwie Polskim [the General Regulations of the Construction Police for cities in the Kingdom of Poland], which were issued in 1820, were in force. These laws concerned mainly fire safety.

They ordered the construction of structures on a foundation and the erection of chimneys of refractory materials. In addition, they obligated to create regulatory plans of cities, taking into account the regulatory lines at which new buildings should be located. The designed objects were to be erected in a ridge arrangement, facing the street. On the other hand, the residential outbuildings should be located at one of the borders and were to be covered with a shed roof. Each person building a new house had to apply for a building permit, presenting the building design together with the site plan to the appropriate governmental bodies. It was forbidden to erect wooden buildings near brick buildings, in city centres or when there were no other non-fireproof buildings nearby, and if they were built, they had to be covered with tiles, additionally the chimney in these buildings had to be made of brick. These regulations also obligated the builder to maintain the aesthetics of the building. They ordered, inter alia, painting houses stone colour, yellowish and pale greenish. In later years, the law was further detailed. The provisions related to fire protection were extended, e.g. balconies and railings made of non-refractory materials were banned. These rules applied mainly in cities [17].

\section{Characteristics of Russian wooden buildings}

Russian wooden buildings were characterized by a great variety, both in terms of functional and spatial arrangements and decorations (Fig. 1). The simplest type were one-story, two-room houses, most often belonging to the less wealthy population. Their spatial arrangement resembled a country cottage, to which utility rooms could be added. Objects with a more extensive program were also erected. Apart from single-storey buildings, two-storey buildings were put up for wealthier people ${ }^{4}$.

Wooden bourgeois houses were most often made of a log or mixed construction, with a brick ground floor and

4 The characteristic functional layouts of bourgeois houses have been arranged in the form of a table in: [18, p. 23, 24].

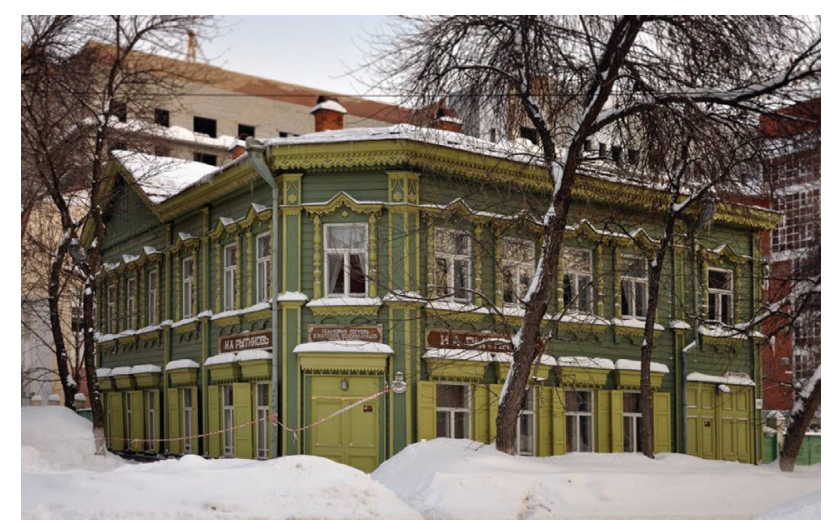

Fig. 1. An example of traditional Russian wooden buildings in Samara (photo by E. Pol, 2011)

I1. 1. Przykład tradycyjnej rosyjskiej zabudowy drewnianej w Samarze (fot. E. Pol, 2011)

wooden storeys above the ground [19]. The external walls were erected in a carcass structure, most often with a charred "dovetail" or "log lock" without remnants, while utility rooms, porches, extensions, towers and bay windows were most often made of a skeleton structure.

Russian architecture was characterized by rich decorations referring to phytomorphic, zoomorphic and geometric forms [20]. The elevations of these buildings were accentuated, among others, by through bay windows, towers (at the corners), breaks (emphasizing the entrance area), balconies and dormers. Towers and bay windows were most often crowned with a hipped roof with a spire, less often bulbous roof or gable roofs were used (Fig. 2).

Wooden built-up windows were an important element with the richest decoration. It could consist of drip and window sill, which together with the window framing formed a decorative frame (Fig. 3a). In addition, shutters were used mainly in the homes of less wealthy society, which were treated as a simpler version of window decoration. Another characteristic element of this type of development are wooden porches (Fig. 3b). They appeared in many forms, from fully built-up ones, to simpler ones, reduced only to the roof above the main entrance.

The façades of traditional wooden buildings were richly decorated (Fig. 4). Wind girders were additional elements which, apart from the function of securing the roof covering against the wind, had a decorative function. These were boards nailed along the edge of the roof, the lower part of which had an ornament in geometric forms, e.g., a diamond or an oval. Also, the corner decoration (Pol. ko$\dot{z}$ uchowanie) served both a protective and decorative function. It was a vertical formwork located in the corners of the building, with decorations of mostly geometric forms.

\section{Wooden housing development in the Lublin region - examples}

The paper presents selected examples of wooden residential architecture in the Lublin region, in which the influences of Russian architecture from the period of intensified repressions after the January Uprising are clearly 


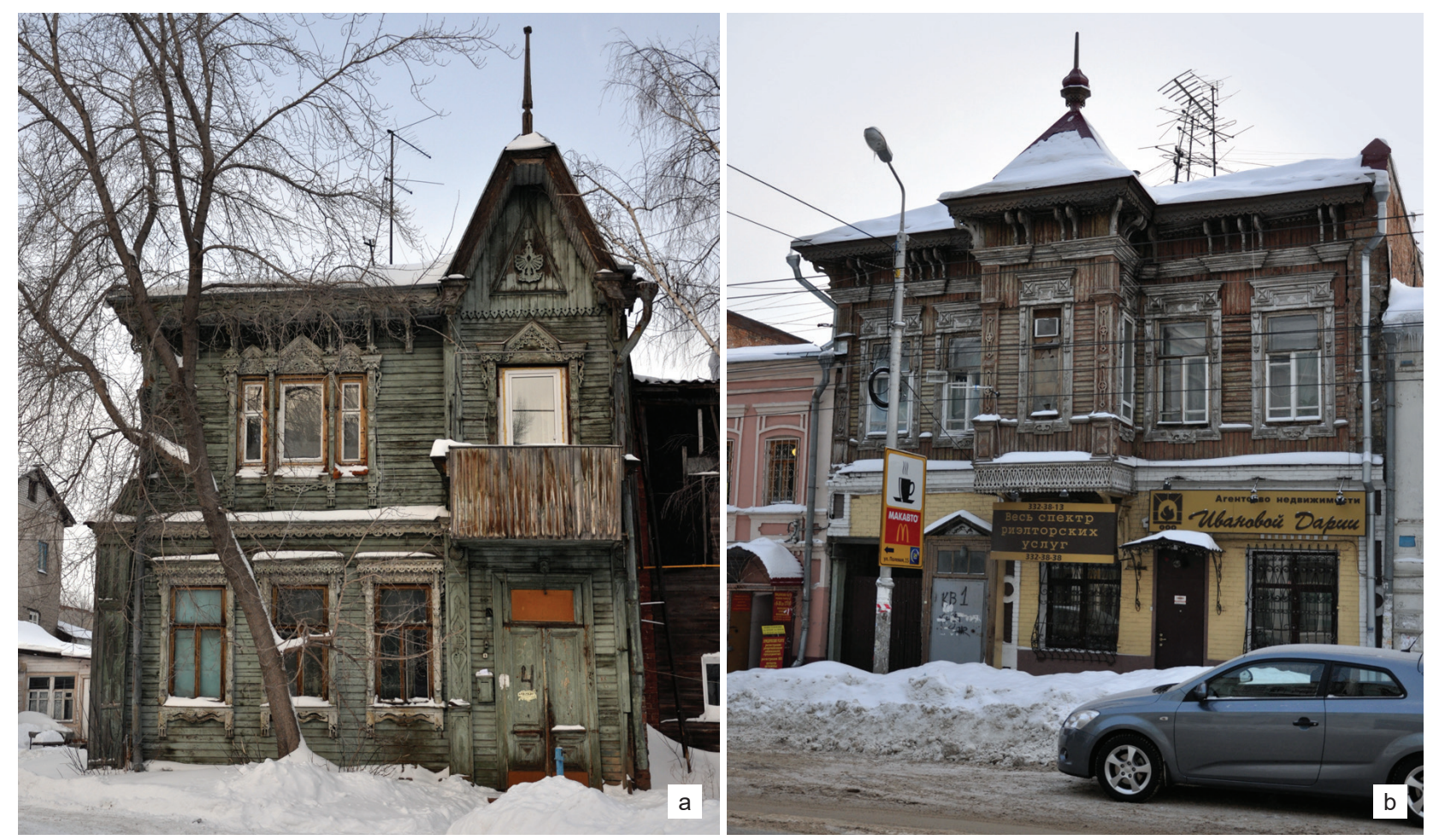

Fig. 2. Two-story wooden houses in Samara (photo by E. Pol, 2012)

Il. 2. Dwukondygnacyjne domy drewniane w Samarze (fot. E. Pol, 2012)
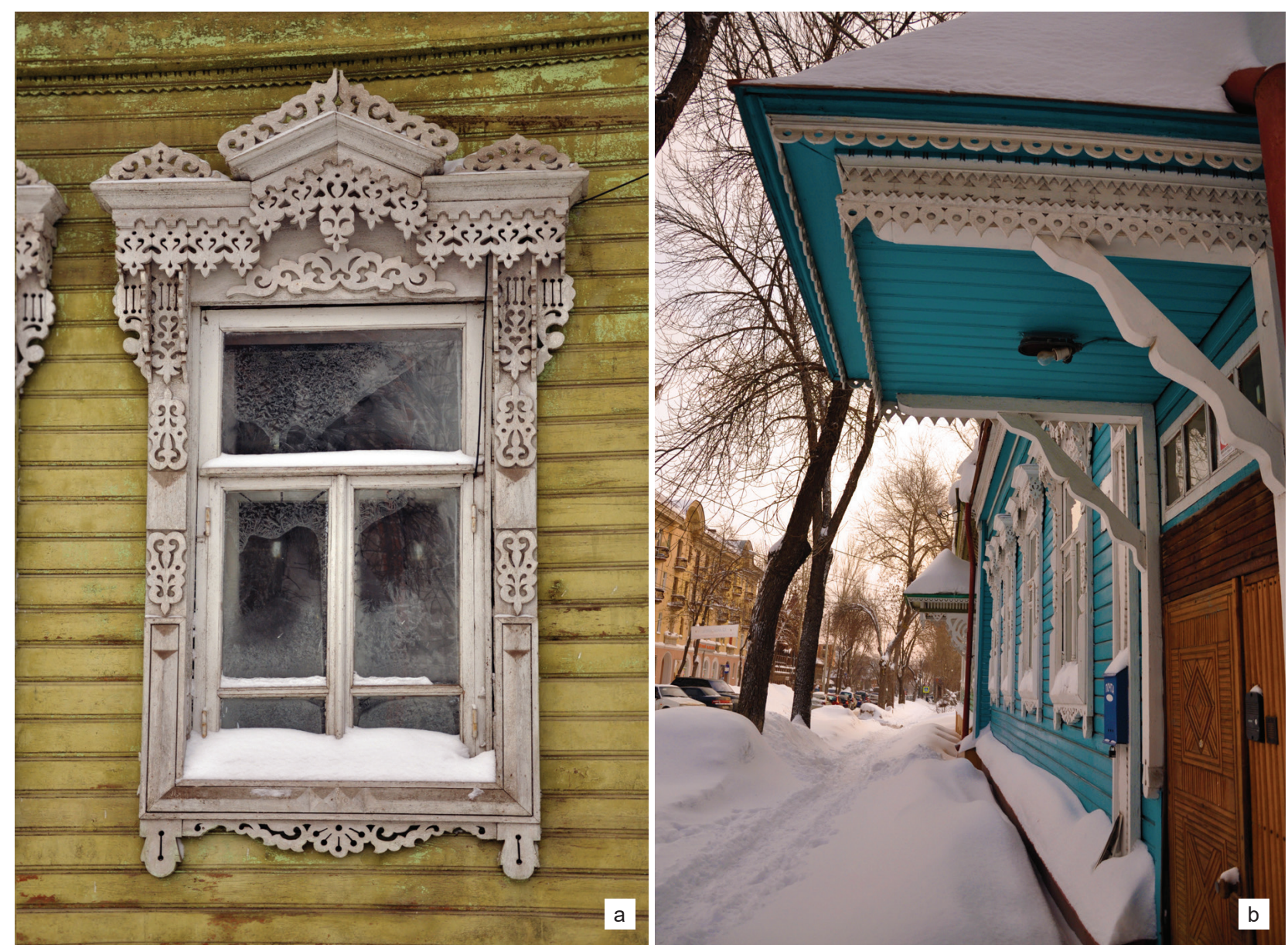

Fig. 3. An example of traditional Russian wooden buildings in Samara: a) window detail, b) porch detail (photo by E. Pol, 2012) Il. 3. Przykład tradycyjnej rosyjskiej zabudowy drewnianej w Samarze: a) detal okna, b) detal ganku (fot. E. Pol, 2012) 
visible. Unfortunately, the sheer scale of stylistic influences of Russian architecture on the objects studied in this area cannot be precisely defined today. The main reasons for this are:

- the state of preservation of the objects from the period in question (in the Lublin region, there are definitely fewer objects of this type than originally built or could have been built, due to, inter alia, war damage, numerous fires and other destructive factors);

- today it is impossible to determine the original number of buildings that were built under the influence of the discussed style due to the lack of not only the buildings themselves, but also their design documentation, which - as already mentioned - was not strictly required for the group of buildings in question until 1928;

- the preserved historical iconography covers only a small percentage of small towns in the Lublin region and does not allow for an unequivocal determination of the scale of the phenomenon, but only documents the condition of individual objects, which can be compared with the present state, as long as the object has survived. Very rarely, iconography gives the opportunity to trace the history of style changes in preserved houses.

Perhaps many of the existing buildings of the type in question originally had the stylish features of Russian architecture, but they were removed after 1918, making analysis impossible. It should also be emphasized that conducting thorough material and architectural research and dating wooden residential architecture based solely on style features and construction techniques, in the absence of the preserved design documentation and iconography, is in the current conditions (technical condition, no conservation protection and ownership status - objects in mostly private or social) made very difficult ${ }^{5}$.

\footnotetext{
${ }^{5}$ Analogies to the style changes of the wooden housing architecture of small towns in the Lublin region can be found in the transformations of the sacred architecture of this area, when many Pounick churches, as well as Roman Catholic churches were transformed in the Russian national style, and new Orthodox churches were built in this style. Many, if not the vast majority of wooden churches in this area were built after the Brest Union, therefore the point of reference for a comparative analysis is mainly the period after 1596. It should be remembered, however, that the transformation processes depended on the political and religious situation. At the end of the $19^{\text {th }}$ century, increased Russification, and thus - the religious situation, led to the transition of many Uniates to the Orthodox Church. As a result of the liquidation of the Uniate Church, the ownership of the Orthodox Church in the Kingdom of Poland increased six-fold [22, pp. 17-21].

During World War I, officials, clergy and part of the population of these areas were evacuated deep into Russia, which resulted in an outflow of both the faithful and the partitioning administration, and Poland's regaining independence in 1918 resulted in the consolidation of Polish interests, which were enforced, often brutally, also in the field of architecture. Similarly to what happened after the Union of Lublin, many Uniate churches were transformed, sometimes demolished, and after 1918, the religious architecture of the former Uniate churches was "cleansed" of Russian influence. As a result, many Pounice churches were transformed into Roman Catholic churches, blurring not only the style features of the Russian influence after the January Uprising, but also the original architectural features of these churches, whether originally Orthodox or later Uniate, built according to the guidelines of the Zamość Synod. The subject of changes in church and religious affiliations is extremely sensitive and widely described in the literature.
}

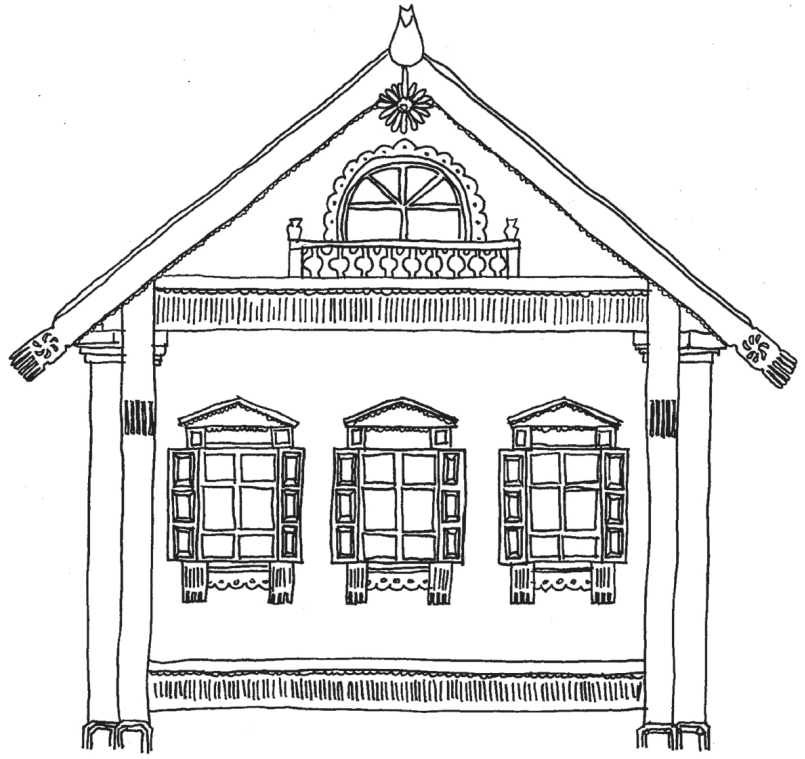

Fig. 4. Traditional Russian wooden construction housing - gable wall (elaborated by E. Netczuk-Pol based on [21])

Il. 4. Tradycyjna rosyjska zabudowa mieszkaniowa o konstrukcji drewnianej - ściana szczytowa (oprac. E. Netczuk-Pol na podstawie [21])

It is worth noting here that in the period in question, objects inspired by styles other than Russian were also created $^{6}$

According to statistical data, in 1845 , out of the total number of 22,742 houses, only 2,103 were made of brick [23]. Brick buildings existed mainly in large cities. Until the beginning of the 1860 s, they did not exist at all in some places, e.g., in Dubienka, Horodło, and Frampol. This was related to the availability of wood as a building material and the speed of construction.

An example of a typical town housing development at the turn of the $19^{\text {th }}$ and $20^{\text {th }}$ centuries with a wooden structure was a house in Kock (Fig. 5). The building is designed on an irregularly shaped plan, similar to a rectangle, with three entrances from the street. It consisted of seven rooms, including three living rooms. There is a similarity to the functional systems of Russian wooden buildings?

As it is not the subject of this study, it will not be developed, but it is one of the aspects and catalysts of changes in the style features of wooden (also brick) Orthodox and Uniate church architecture, as well as housing.

6 In the $19^{\text {th }}$ century, the interest in nature and hydrotherapy increased, which contributed to the development of health resorts and towns such as Nałęczów. Most of the buildings erected at that time were of wooden construction, referring to the spa style architecture in Switzerland and Germany. They had a detail with geometric, phytomorphic forms, which appeared, e.g., in the decoration of windows, doors and verandas. In the health resorts of the Lublin region, we can also find examples of references to the Zakopane style. One of the authors of these projects was Jan Koszczyc-Witkiewicz, nephew of Stanisław Witkiewicz. In the Lublin region, an example of a housing development in which the influence of Zakopane style architecture can be seen is a one-story house with an attic located in Dęblin at 22 Stawska Street.

7 An overview of the functional layouts can be found in the work by E.A. Sysoeva [18]. 


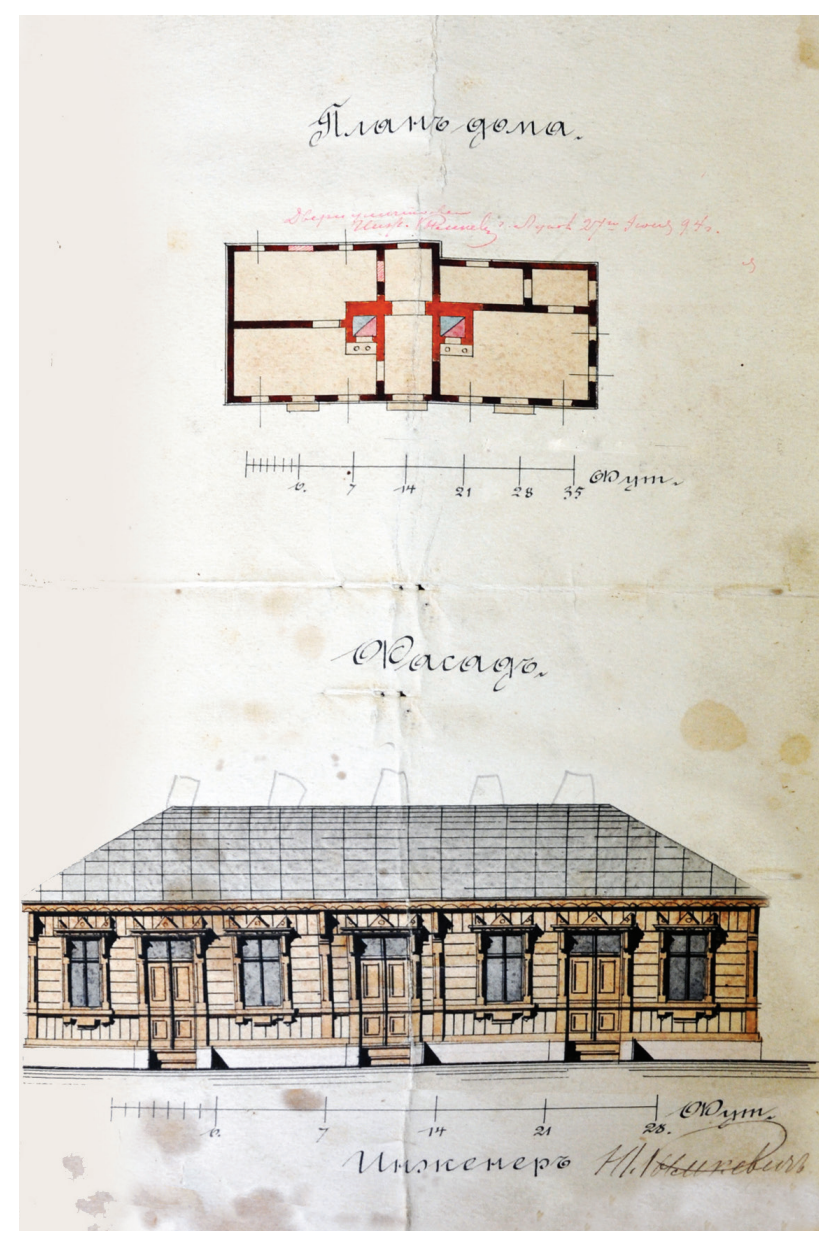

Fig. 5. Plan of a house in Kock from 1900 (source: APL AMK, sygn. 350)

I1. 5. Plan domu mieszkalnego w Kocku z 1900 r. (źródło: APL AMK sygn. 350)
The front façade was symmetrical with seven axes. The windows had decorative frames with drip and window sil1s. Doors with transoms were decorated in a similar way. The corners have been accentuated by a decorative corner with a detail of geometric forms. The façade was entirely boarded with formwork in a vertical arrangement up to the height of the sill cornice, and the rest in a horizontal arrangement. It referred to the features of the Russian national style.

An interesting example is a two-story log house built in 1895 for the director of a sugar factory in Klemensów ${ }^{8}$. It has a much more extensive functional and utility program. As in the previous building, its windows have characteristically decorated drip and window sills, as well as vertical and horizontal planks with no architectural details (Fig. 6).

The development of the railroads at the end of the $19^{\text {th }}$ century was of great importance for the flourishing of the cities. The railway line on the Vistula, established in 1887, connected Warsaw with Kowel, and later with Brześć nad Bugiem and Lwów [25], creating a great development potential for the towns situated alongside it (including Chełm, Hrubieszów and Dęblin).

Along with the development of rail transport, the movement of the population also increased, which introduced its building traditions along with settling in these areas. Hrubieszów is a city where the influence of the invader on the appearance of architecture was significant, which is mainly reflected in architectural details. Most of the onestory houses had decorated porches (Fig. 7). In the case

\footnotetext{
8 The building underwent a major renovation in 2010. Its original function was changed from residential to commercial. There is a restaurant in the basement, while guest rooms are located on the first floor [24].
}

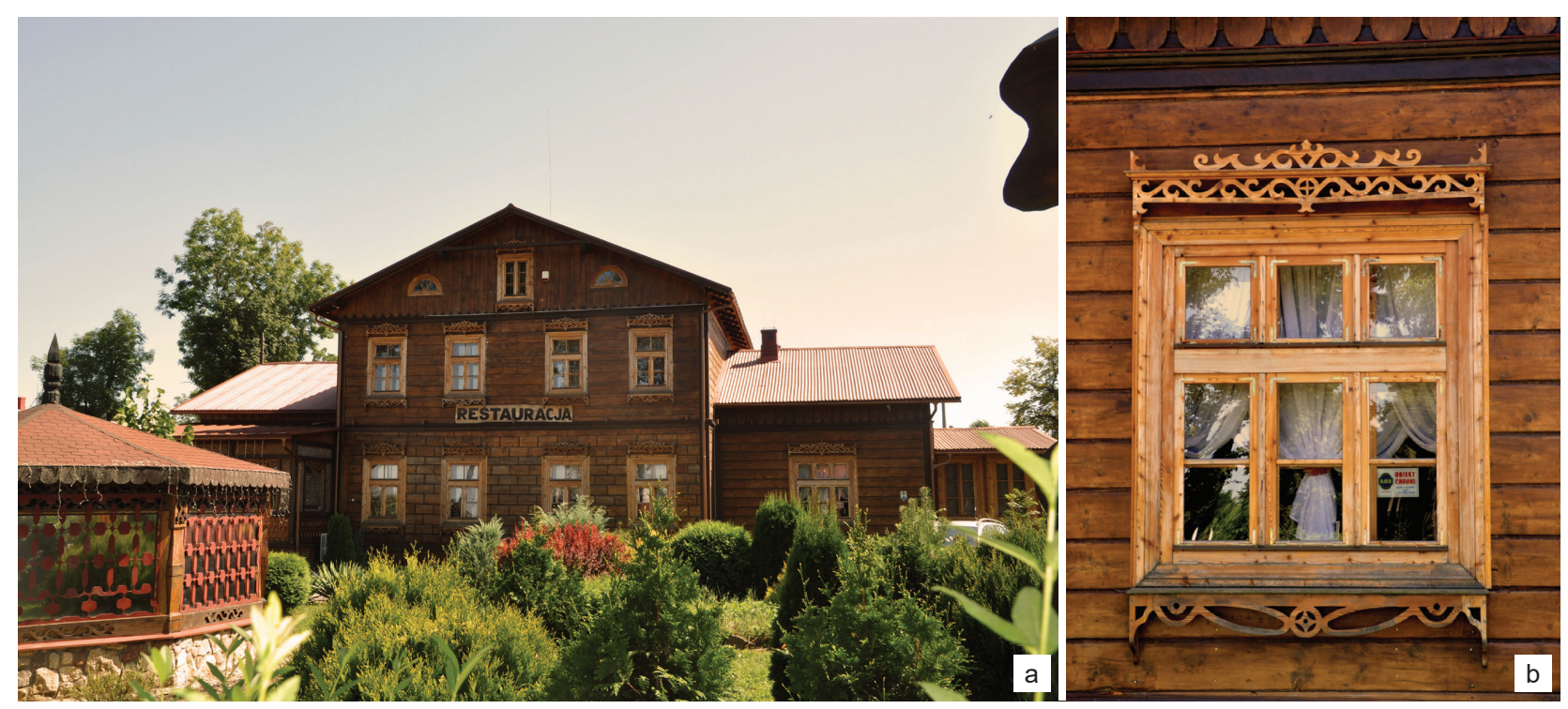

Fig. 6. A residential building from 1895, located in Słodka Street in Szczebrzeszyn - formerly the house of the director of the Sugar Factory Klemensów, now a restaurant: a) view from Skłodowskiej Street, b) detail of the window (photo by E. Pol, 2013)

Il. 6. Budynek mieszkalny z 1895 r. mieszczący się przy ul. Słodkiej w Szczebrzeszynie - dawniej dom dyrektora Cukrowni Klemensów, obecnie restauracja: a) widok od strony ul. Skłodowskiej, b) detal okna (fot. E. Pol, 2013) 

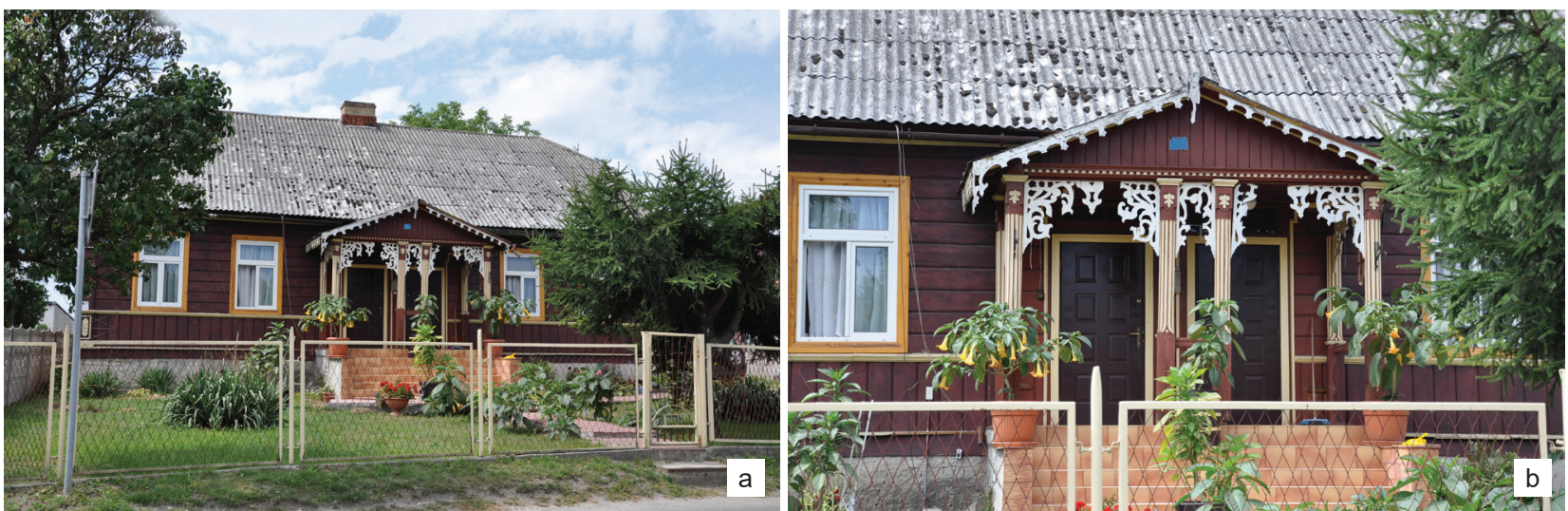

Fig. 7. A one-story residential house in Zamojska Street in Hrubieszów: a) front elevation, b) porch details (photo by E. Pol, 2013)

Il. 7. Parterowy dom mieszkalny przy ul. Zamojskiej w Hrubieszowie: a) elewacja frontowa, b) detale ganku (fot. E. Pol, 2013)
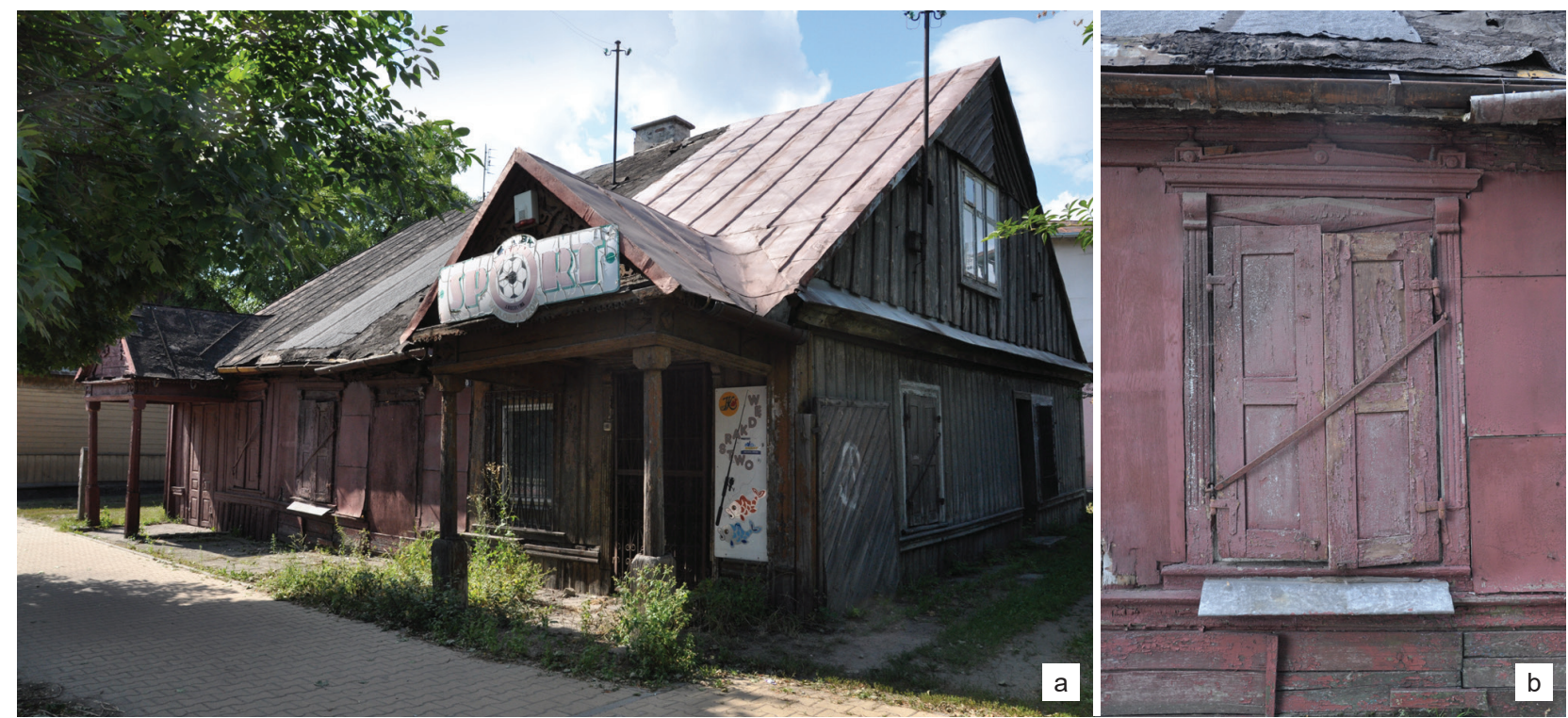

Fig. 8. House in Warszawska Street in Dęblin: a) general view, b) detail of a window with a shutter (photo by E. Pol, 2013)

Il. 8. Dom przy ul. Warszawskiej w Dęblinie: a) widok ogólny, b) detal okna z okiennicą (fot. E. Pol, 2013)

of one-story buildings with an attic, the entrance area was accentuated by attics with loggias or bay windows.

As already mentioned, after the January Uprising, the partitioning state authorities introduced large repressions. At that time, there was a need to create barracks for other military units, and Chełm was to become a garrison town [26]. An example of a wooden barracks together with the accompanying residential buildings are the buildings in Lubelska Street in Chełm. The buildings referred to the Russian wooden buildings. They were made of logs with remnants. The window and door had rich decoration of drip and window sills as well as door bands. Residential buildings in the barracks area additionally had porches (see [27]).

Another city where Russian troops were stationed was Dęblin. It was here in 1893 that one of the first aeronautical troops of the tsarist army equipped with observation balloons was established [28]. The presence of the Russian population influenced the shape of the city's build- ings. In one of the main streets, wooden buildings were built, referring to traditional Russian architecture. It is visible mainly in the decoration of window trims and porch gables (Figs. 8, 9).

References to the traditional Russian wooden buildings can also be found in other cities of the Lublin region. Examples include houses in Ostrów Lubelski or Kock (Fig. 10).

\section{Conclusions}

In the Lublin region - during the partitions under the tsar's rule - the authorities tried in many ways to russify the society. This was also reflected in the architecture, the shape of which was largely influenced by Russian legislation (e.g., building houses on a foundation, building balconies and bay windows made of refractory materials, or using the colours available in the colour chart), the lack of Polish universities educating architects, as well as the 


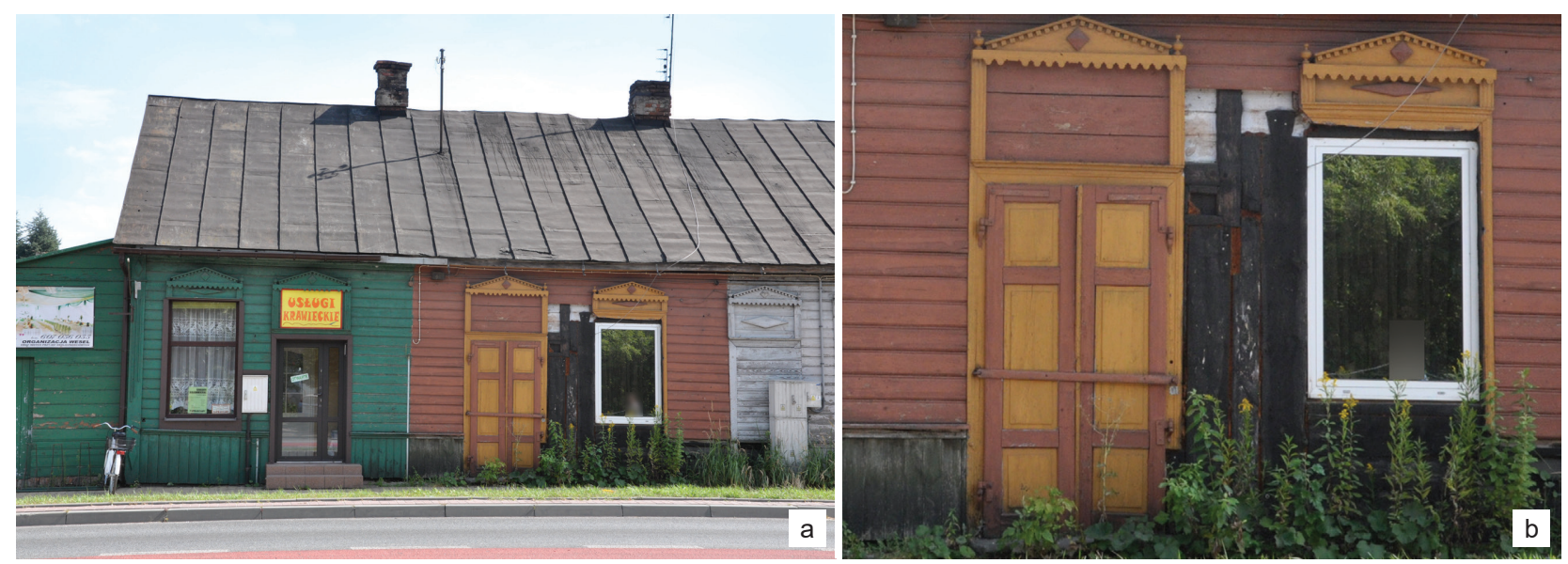

Fig. 9. Wooden buildings in Warszawska Street in Dęblin: a) general view, b) detail of the door and window (photo by E. Pol, 2013)

Il. 9. Zabudowa drewniana przy ul. Warszawskiej w Dęblinie: a) widok ogólny, b) detal drzwi i okna (fot. E. Pol, 2013)
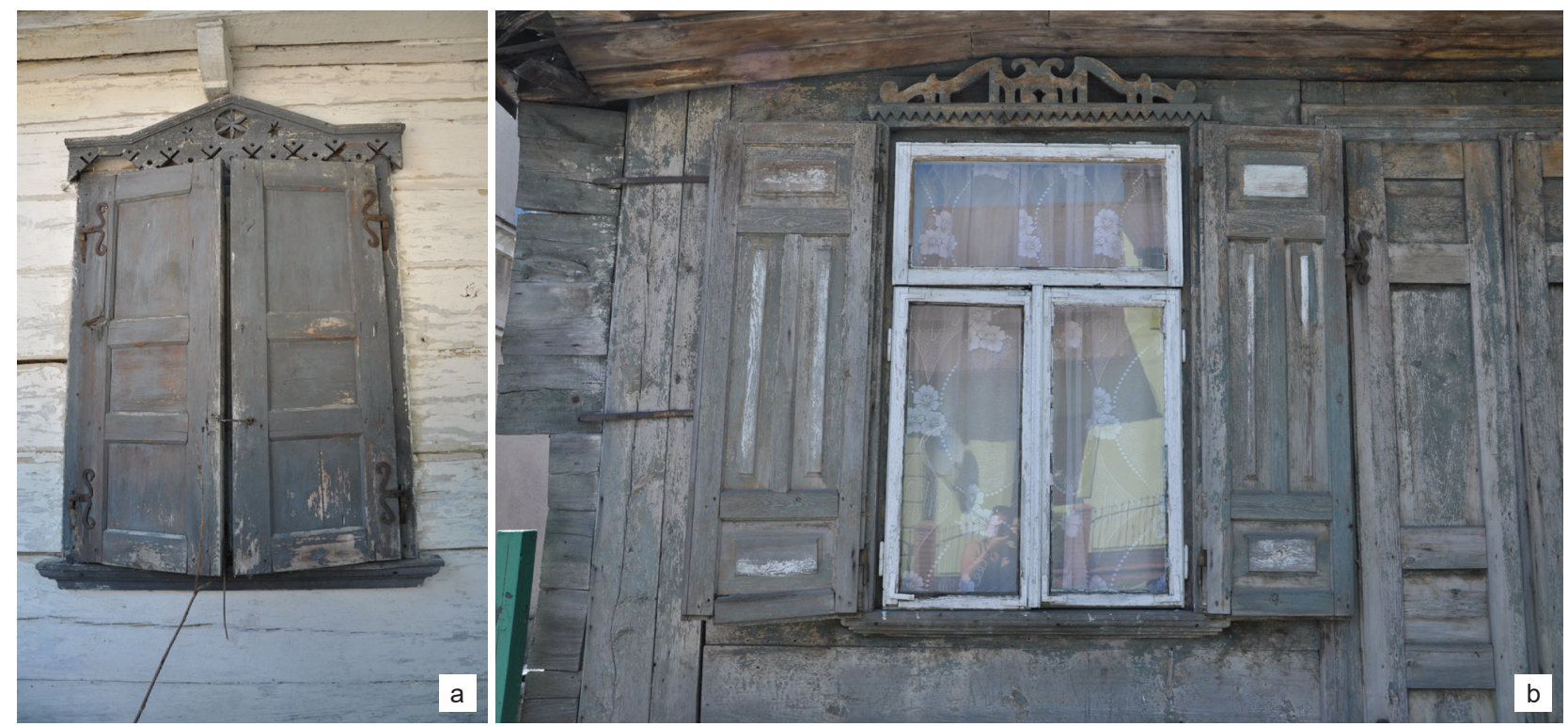

Fig. 10. A window frame with a decorative window drip and shutters in a one-story single-family house:

a) in July 22 Street (currently May 3 Street) in Kock (defunct), b) in Czerwonego Krzyża Street in Ostrów Lubelski (photo by E. Pol, 2013)

Il. 10. Obramienie okienne $z$ dekoracyjnym nadokiennikiem oraz okiennicami w parterowym domu jednorodzinnym:

a) przy ul. 22 lipca (ob. 3 Maja) w Kocku (nieistniejący), b) przy ul. Czerwonego Krzyża w Ostrowie Lubelskim (fot. E. Pol, 2013)

influx of Russian population related to the stationing of the invaders' troops, the staffing of important administrative positions and simply the development of cities along the newly created railway line.

The wooden structures erected at that time were characterized by exceptional architectural detail of the facades. Windows and doors in the Russian pattern were richly decorated with frames and shutters. Corners, the so-called pol. winkle, accentuated with decorative corners with geometric and phytomorphic forms, but in most cases they did not have an ornament. The entrance zone was emphasized by adding porches with gable roofs supported on pillars to the main body of the building or, in the case of houses with an attic, through an attic with a balcony or bay window.
Currently, it is difficult to show in situ how many buildings were erected in the Russian style, as the building law did not require the submission of a project at the time. In addition, numerous armed struggles that took place in this area destroyed many buildings. Due to the wooden material, this type of residential buildings is not durable. Some of the houses, although surviving the turmoil of war, did not survive due to material wear and biological corrosion, and those that still exist today, most of them underwent numerous modernizations involving the replacement of woodwork or insulation, which makes it impossible to recreate the original detail.

Translated by Ewa Netczuk-Pol 


\section{References}

[1] Omilanowska M., Polscy architekci w petersburskiej Akademii Sztuk Pięknych w latach 1814-1918, "Biuletyn Historii Sztuki" 2004, t. $66, \mathrm{nr} 3 / 4,351-373$.

[2] Zin W., Narodziny krajobrazu kulturowego, Wyższa Szkoła Informatyki i Zarządzania z siedzibą w Rzeszowie, Rzeszów 2005.

[3] Górak J., Budownictwo Drewniane Lubelszczyzny. Stan badań, bibliografia, inwentaryzacje, Wydawnictwo Lubelskie, Lublin 1977.

[4] Górak J., Regionalne formy architektury drewnianej Lubelszczyzny na tle zagadnień osadniczych, Państwowa Służba Ochrony Zabytków, Zamość 1994.

[5] Gierowski J.A., Historia Polski 1764-1864, PWN, Warszawa 1987.

[6] Mencel T., Między powstaniami 1831-1864, [w:] J. Mazurkiewicz, H. Zins (red.), Dzieje Lubelszczyzny, t. 1, PWN, Warszawa 1974.

[7] Przesmycka E., Lubelszczyzna. Wielokulturowość osadnictwa, budownictwa $i$ architektury, Wydawnictwo Politechniki Lubelskiej, Lublin 2008.

[8] Dziennik praw Królestwa Polskiego, t. 20, nr 68-70, http://pbc.biaman.pl/dlibra/docmetadata?id=4390\&from=publication [accessed: 11.09.2014].

[9] Adminisfracya rosyjska w Królestwie Polskiem, Wydawnictwo Naczelnego Komitetu Narodowego, Wiedeń 1915.

[10] Przesmycka E., Przeobrażenia zabudowy i krajobrazu miasteczek Lubelszczyzny, Wydawnictwo Politechniki Lubelskiej, Lublin 2001.

[11] Buczko J., Historia Polski 1864-1948, PWN, Warszawa 1987.

[12] Sokoł K., Sosna A., Kopuly nad Wisła. Prawosławne cerkwie w centralnej Polsce w latach 1815-1915, MID "Synergia", Moskwa 2003.

[13] Paszkiewicz P., Pod berłem Romanowów: sztuka rosyjska w Warszawie 1815-1915, Instytut Sztuki PAN, Warszawa 1991.

[14] Baraniewski W., Między opresja a obojętnością. Polsko-rosyjskie relacje architektoniczne $w X X$ wieku, M. Poprzęcka, L. Jowlewa (red.), Warszawa - Moskwa/Moskwa - Warszawa 1900-2000, katalog wystawy, Narodowa Galeria Zachęta - Galeria Tretiakowska, Zachęta - Narodowa Galeria Sztuki, Warszawa 2004, 98-107.
[15] Chomicki J., Powstanie i rozwój układu urbanistycznego Międzyrzeca od średniowiecza do czasów obecnych, "Rocznik Międzyrzecki” 1988-1990, R. 20-22, 78-169.

[16] Przesmycka E., Wpływ przepisów prawnych na obraz miast w zaborze rosyjskim na przykładzie Lubelszczyzny, "Architectus” 2002, nr 2(12), 79-87.

[17] Przepisy Ogólne Policji Budowniczej dla miast w Królestwie Polskim, 1820.

[18] Sysoeva E.A., Osobennosti derevyanoy arkhitektury Samary konca XIX-nachala XX vekov, Niżny Nowogród 2009.

[19] Sysoeva E.A., Gradostroitelnye predposylki $i$ osobennosti razvitiya derevyannoy zastroyki konca XIX-nachala XX veka, "Vestnik Tomskogo Gosudarstvennogo Arkhitekturno-strotelnogo Universiteta" 2008, No. 4, 58-69.

[20] Pol E., Architektura drewniana Samary końca XIX i poczatku XX wieku, "Teka Komisji Architektury, Urbanistyki i Studiów Krajobrazowych" 2011, t. 7, 183-196.

[21] Sobolev A., Derevyanyj dom. O derevne i vremeni zagotovki lesa, ELPA, Archangielsk 2003.

[22] Pelica G.J., Kościól prawosławny w województwie lubelskim (19181939), Fundacja Dialog Narodów, Lublin 2007.

[23] Kalinowski W., Trawkowski S., Uwagi o urbanistyce i architekturze miejskiej Królestwa Kongresowego w I połowie XIX wieku, "Studia i Materiały do Teorii i Historii Architektury i Urbanistyki", t. 1, PWN, Warszawa 1956.

[24] http://www.polskaniezwykla.pl/web/place/40204,szczebrzeszyn -karczma-z-muzeami.html [accessed: 10.09.2019].

[25] Droga Żelazna Nadwiślańska, “Andriollówka” 2011, nr 26.

[26] Sobieraj M., Pod skrzydłami dwóch czarnych orłów. Wojskowe dzieje Chetma w latach 1889-1918, "Chełmskie Zeszyty Historyczne" 1993, t. 1, 11-12.

[27] Koszary 65. Moskiewskiego Pułku Piechoty, W. Smyk (photo), https:// fotopolska.eu/529373,foto.html?o=b125577 [accessed: 12.05. 2019].

[28] Dęblin, https://pl.wikipedia.org/wiki/D\%C4\%99blin\#Historia [accessed: 10.09 .2019$]$.

\section{Abstract \\ The influence of the foreign invader on the shape of wooden architecture of the end of the $19^{\text {th }}$ and beginning of the $20^{\text {th }}$ century in the Lublin region}

The aim of the article was to present the influence of the Russian national architecture on the wooden architecture of the Lublin region, created at the turn of the $19^{\text {th }}$ and $20^{\text {th }}$ centuries, which was characterized by great distinctiveness. The subject of the work was to show the importance of increased Russification, which touched not only the spheres of social and cultural life, but also architecture.

The article analyzes the preserved wooden architecture from the turn of the century in the present-day Lubelskie Region. The starting material used was the available archival materials and documentation prepared for the needs of the provincial conservator of monuments (the card for the records of architectural and construction monuments) and a local inspection was made to prepare photographic documentation of the current state. Characteristic wooden buildings were used as comparative material, built at the end of the $19^{\text {th }}$ and the beginning of the $20^{\text {th }}$ century in Samara, Russia. The buildings have a well-documented history and are well researched by local scientists. Additionally, they are kept almost intact.

During the research, a comparative method was used for the existing wooden buildings in the Lublin region from the turn of the century with the Russian wooden buildings, mainly in terms of detail and façade decoration. It allowed us to notice the similarities between the details used in traditional wooden construction in the Lublin Province. It is especially visible in the details of the window decorations - richly decorated drip and window sills. It is an element characteristic only for the analyzed period, which confirms the thesis about the influence of the foreign invaders on the shape of architecture.

Key words: wooden buildings, Lublin region, Russification, turn of the $19^{\text {th }}$ and $20^{\text {th }}$ centuries

\section{Streszczenie}

\section{Wplyw zaborcy na ksztalt architektury drewnianej końca XIX i poczatku XX w. na terenie Lubelszczyzny}

Celem artykułu było przedstawienie wpływu architektury narodowej rosyjskiej na drewnianą architekturę Lubelszczyzny powstałą na przełomie XIX i XX w., która charakteryzowała się dużą odrębnością. Przedmiotem pracy było ukazanie znaczenia wzmożonej rusyfikacji, która dotykała nie tylko sfery życia społecznego, kulturalnego, ale także architektury.

W artykule dokonano analizy zachowanej architektury drewnianej powstałej na przełomie wieków na terenie obecnego województwa lubelskiego. Jako materiał wyjściowy wykorzystano dostępne materiały archiwalne oraz dokumentację stworzoną na potrzeby wojewódzkiego konserwatora 
zabytków (karta ewidencji zabytków architektury i budownictwa) oraz dokonano wizji lokalnej w celu przygotowania dokumentacji fotograficznej stanu aktualnego. Jako materiał porównawczy posłużyła charakterystyczna zabudowa drewniana powstała pod koniec XIX i na początku XX w. w Samarze w Rosji. Zabudowa ta ma dobrze udokumentowaną historię oraz jest dobrze zbadana przez lokalnych naukowców. Dodatkowo przetrwała do dziś w stanie prawie nienaruszonym.

Podczas badań porównano istniejącą zabudowę drewnianej Lubelszczyzny z przełomu wieków z zabudową drewnianą rosyjską przede wszystkim pod względem detalu i dekoracji fasady. Pozwoliło to na zauważenie podobieństw między detalami stosowanymi w tradycyjnym budownictwie drewnianym na terenie województwa lubelskiego. Szczególnie jest to widoczne w detalu stolarki okiennej - bogato dekorowane nad- i podokienniki. Jest to element charakterystyczny tylko dla badanego okresu, co potwierdza tezę o wpływie zaborcy na kształt architektury.

Słowa kluczowe: zabudowa drewniana, Lubelszczyzna, rusyfikacja, przełom XIX i XX w. 